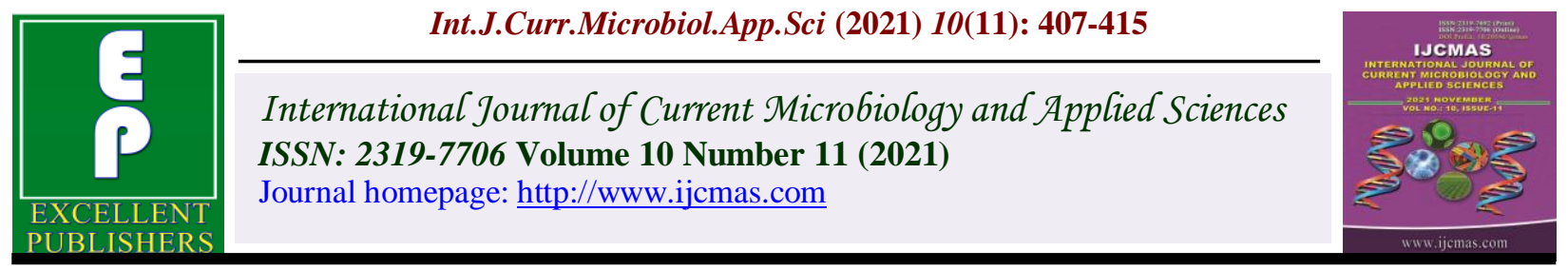

\title{
Bio-Control Efficiency of Trichoderma viride against Stem Rot of Tuberose Caused by Sclerotium rolfsii
}

\author{
N. H. Sankara Reddy*, T. Sivakumar and P. Balabaskar
}

Department of Plant Pathology, Faculty of Agriculture, Annamalai University, Annamalai Nagar, Chidambaram - 608002, Tamil Nadu, India

*Corresponding author

Keywords

Tuberose,

Sclerotium rolfsii,

Trichoderma viride

Article Info

Received:

18 October 2021

Accepted:

06 November 2021

Available Online:

10 November 2021

Tuberose is an important flower crop for cut flower and decorations which is a chief raw material for the production of high-grade perfumes. Recent days stem rot of tuberos is an important disease that affects the quality of flowers. The objective of this paper is to evaluate the efficiency of $T$. viride isolates against $S$. rolfsii and improves growth parameters of tuberose. Among the different antagonists tested, Trichoderma is found be very effective against $S$. rolfsii. The isolates $T$. viride are named as $\mathrm{Tv}_{1}-\mathrm{Tv}_{10}$. The efficient isolate have been identified as $\mathrm{Tv}_{5}$ by dual culture technique, which shows maximum mycelial inhibition (77.15), this was followed by the isolates $\operatorname{Tv}_{4}(75.94)$ and $\operatorname{Tv}_{1}$ (72.96) in the decreasing order, the least growth inhibition of pathogen was exhibited by the isolate $\operatorname{Tv}_{10}(55.72 \%)$. The poison food technique @ $40 \%$ concentration completely inhibits the mycelial growth on solid media.

\section{Introduction}

Tuberose (Polianthes tuberosa L.) is a commercially important ornamental bulbous plant cultivated in the world as well as in India for cut and loose flower trade. The losses due to stem rot disease may go up to 50-60 per cent (Kakade, 2007). In Tamil Nadu the losses due to stem rot ranges from 25-40 per cent (Theradimani et al., 2018). The area under tuberose cultivation in India is about 14.92
' 000 ha with a production of 106.49 ' $000 \mathrm{MT}$ of loose flowers and 89.83 lakh nos. of cut flowers in 2016-17 (www.indiastat.com). Total export of floriculture products during the year 2015-16 was 22,518 MT with value of Rs. 479 crores (www.apeda.gov.in).

Different species of bacteria Bacillus subtilis, Pseudomonas fluorescens and fungi Trichoderma viride are reported to be effective. The effectiveness of several bio- 
control agents against several soil borne pathogens were recorded (Sivasakthi et al., 2014; Zape et al., 2014; Gowdra Nagamma, 2015). Among that $T$. viride is one of the best to control soil borne plant pathogens. Biocontrol agents are gaining importance due to their plant growth promoting and diseases reduction capabilities (Thahir Basha et al., 2012).

Several workers reported that successful application of antagonists can control $S$. rolfsii in various crops (Parmar et al., 2015; Dwivedi et al., 2016; Ramzan et al., 2016). Using compatible strains of plant growth promoting and bio-control microorganisms such as Trichoderma spp to maximize plant growth has been globally demonstrated (Srivastava et al., 2010; Singh and Singh, 2014).

\section{Materials and Methods}

\section{Isolation and purification of $T$. viride}

Soil samples were collected from rhizosphere soil of tuberose for the isolation of Trichoderma spp. Samples were brought to laboratory and stored at $4{ }^{\circ} \mathrm{C}$ until used. Fivefold serial dilutions of each soil samples were prepared in sterilized distilled water and 0.5 $\mathrm{ml}$ diluted sample was poured on the surface of Trichoderma specific medium (TSM) (Elad and Chet, 1983). Plates were incubated at $28 \pm 2{ }^{\circ} \mathrm{C}$ for $48-72 \mathrm{hrs}$. Isolated colonies were further purified by single hyphal tip and plating on PDA medium. Purified cultures are stored in agar slants for further use.

Morphological identification was done based on cultural characterization and microscopic observation (Savitha and Sriram, 2015). For morphological characterization of these isolates, characters describing colony morphology, conidial size and breadth $(\mu \mathrm{m})$. Microscopic observations were followed by $3 \% \mathrm{KOH}$ mount and slide culture technique stained with lacto phenol cotton blue and examined with fluorescent microscope.

\section{Dual culture technique}

The antagonistic activity of bio control agents $\left(\mathrm{Tv}_{1}-\mathrm{Tv}_{10}\right)$ against $S$. rolfsii was tested by dual culture technique (Dennis and Webster, 1971). At one end of the sterile Petri dish containing $15 \mathrm{ml}$ of solidified PDA medium a seven $\mathrm{mm}$ mycelial disc obtained from five days old culture of Trichoderma spp. was placed under aseptic conditions. Similarly, at the opposite end approximately $75 \mathrm{~mm}$ away from the Trichoderma culture disc, a seven $\mathrm{mm}$ mycelial disc obtained from seven days old culture of $S$. rolfsii was placed and incubated. A control was maintained by inoculating $S$. rolfsii alone at one end of the Petri dish. The plates were incubated at room temperature (28 $\pm 2^{\circ} \mathrm{C}$ ) for seven days.

Per cent inhibition

(I) $=\frac{\mathrm{C}-\mathrm{T}}{\mathrm{C}} \times 100$

Where, C- mycelial growth of pathogen in control

$\mathrm{T}$ - mycelial growth of pathogen in dual plate

I - inhibition Percent

Based on the dual culture technique the effective $T$. viride were identified and used for further studies.

\section{Poison food technique}

PDA medium was prepared in $100 \mathrm{ml}$ conical flask and autoclaved. Filtered antagonistic poison of Trichoderma of 5, 10, 15 and $20 \mathrm{ml}$ were added to $45,40,35$ and $30 \mathrm{ml}$ aliquots respectively in flasks so as to get the final concentration of $10,20,30$ and 40 per cent. 
The incorporation of fungicide carbendazim @ $0.1 \%$ in the medium was used for comparison. PDA medium without culture filtrate served as control. Each plate was inoculated at the center with a seven old culture disc $(6 \mathrm{~mm})$ of pathogen and incubated at room temperature $\left(28 \pm 2^{\circ} \mathrm{C}\right)$.

\section{Results and Discussion}

\section{Cultural characteristics of $S$. rolfsii isolates}

Growth and cultural characters of native $T$. viride isolates

A total of ten isolates of $T$. viride were able to be isolated from tuberose rhizosphere soil in different localities. The colony characters of ten native isolates of $T$. viride were observed visually on third and seventh day after inoculation and the results are presented in table 2 . The colony morphology of the isolates $\left(\mathrm{Tv}_{1}, \mathrm{Tv}_{4}, \mathrm{Tv}_{8}\right.$ and $\left.\mathrm{Tv}_{9}\right)$ was almost similar and showed profuse white to green mycelium. The isolates $\left(\mathrm{Tv}_{3}, \mathrm{Tv}_{7}, \mathrm{Tv}_{8}\right.$ and $\left.\mathrm{Tv}_{10}\right)$ showed moderate white mycelial growth. The colonies reached $80-90 \mathrm{~mm}$ diameter within five days at room temperature $\left(28 \pm 2^{\circ} \mathrm{C}\right)$. Sporulation started after $48 \mathrm{~h}$ of incubation for all the isolates. The conidiophores showed typical pyramidal branching viz., short branches near the tip and longer branches with frequent branching at the bottom. The conidia of $\mathrm{Tv}_{5}$ were almost globose and measured 2.80 $3.75 \mu \mathrm{m}$ length and $2.50-5.10 \mu \mathrm{m}$ breath was recorded as large compared to other isolates. The cultural and morphological characteristics of Trichoderma native isolates agreed with those described by Domsch et al., (1980) and therefore ten isolates were identified as $T$. viride and designated as $\mathrm{Tv}_{1}$ to $\mathrm{Tv}_{10}$. Trichoderma is worldwide in occurrence and can be easily isolated from soil. The capability of Trichoderma as bio control agent against plant diseases has been reported by several workers (Wells et al., 1972; Sharon et al., 2001). Antagonistic effects of Trichoderma against $S$. rolfsii have already been reported by various other researchers on different hosts (Chet, 1987; Elad et al., 1983; Harman et al., 1980; Papavizas, 1985; Prasun, 1997).

In the present study $\mathrm{Tv}_{5}$ has highly efficient in reduction of stem rot of tuberose under in vitro and in vivo conditions. The inhibitor effect is due to different mechanisms viz., competition, parasitism, antibiosis and lysis.

\section{In vitro efficacy of $T$. viride against $S$. rolfsii $\left(\mathrm{Sr}_{1}\right)$ by Dual culture method}

In general, all the native $T$. viride isolates tested significantly inhibited the mycelial growth of $S$. rolfsii (Table 2). However, among the isolate $\mathrm{Tv}_{5}$ showed the maximum growth inhibition of $S$. rolfsii up to 77.15 per cent respectively. This was followed by the isolates $\mathrm{Tv}_{4}$ (75.94) and $\mathrm{Tv}_{1}$ (72.96) in the decreasing order, the least growth inhibition of pathogen was exhibited by the isolate $T v_{10}$ $(55.72 \%)$. These results are in agreement with earlier workers (Karthikeyan et al., 2006; Darvin et al., 2013; Padmaja et al., 2013; Pan et al., 2013; Swathi et al., 2015; Dwivedi and Ganesh Prasad, 2016; Hirpara et al., 2017) (Plate 1).

Sala et al., (2007) studied on the effectiveness of Trichoderma as bio-control agent against a number of soil-borne pathogens (Pythium sp., Rhizoctonia solani and Sclerotium rolfsii) and reported that the inhibition is due to several mechanisms, such as antibiosis, mycoparasitism, induction of defense responses and other adjunct mechanisms, such as growth promotion. 
Table.1 Isolation and cultural characters of native isolate Trichoderma viride

\begin{tabular}{|c|c|c|c|c|c|}
\hline S.No & Isolates & Locality & Colony morphology & \multicolumn{2}{|c|}{ Conidia size } \\
\cline { 6 - 7 } & & & Length & $\begin{array}{c}\text { Breadth } \\
(\boldsymbol{\mu})\end{array}$ \\
\hline $\mathbf{1}$ & $\mathrm{Tv}_{1}$ & Palwadi & $\begin{array}{c}\text { Profuse mycelium with dark } \\
\text { green sporulation }\end{array}$ & $2.35-3.30$ & $2.20-4.50$ \\
\hline $\mathbf{2}$ & $\mathrm{Tv}_{2}$ & Varagur & $\begin{array}{c}\text { Whitish green mycelium with } \\
\text { dull sporulation }\end{array}$ & $2.10-3.10$ & $2.05-4.00$ \\
\hline $\mathbf{3}$ & $\mathrm{Tv}_{3}$ & Baisuhalli & $\begin{array}{c}\text { Moderate white mycelium with } \\
\text { bright green sporulation }\end{array}$ & $2.20-3.20$ & $2.40-4.30$ \\
\hline $\mathbf{4}$ & $\mathrm{Tv}_{4}$ & Pulikurai & $\begin{array}{c}\text { Initial white mycelium later } \\
\text { becomes fluffy green }\end{array}$ & $2.55-3.30$ & $2.40-4.70$ \\
\hline $\mathbf{5}$ & $\mathrm{Tv}_{5}$ & Karagathahalli & Bright green sporulation & $2.80-3.75$ & $2.50-5.10$ \\
\hline $\mathbf{6}$ & $\mathrm{Tv}_{6}$ & Kadampatti & $\begin{array}{c}\text { Thin white mycelium with } \\
\text { complete green sporulation }\end{array}$ & $2.00-3.15$ & $2.25-4.10$ \\
\hline $\mathbf{7}$ & $\mathrm{Tv}_{7}$ & Perungulathur & $\begin{array}{c}\text { Initially dull white mycelium } \\
\text { later becomes dark green }\end{array}$ & $2.30-3.00$ & $2.00-4.00$ \\
\hline $\mathbf{8}$ & $\mathrm{Tv}_{8}$ & Vanapurm & $\begin{array}{c}\text { profuse mycelium later become } \\
\text { cottony and green sporulation }\end{array}$ & $2.35-2.90$ & $2.40-3.85$ \\
\hline $\mathbf{9}$ & $\mathrm{Tv}_{9}$ & Royandpuram & $\begin{array}{c}\text { Profuse mycelium with green } \\
\text { sporulation }\end{array}$ & $2.20-3.00$ & $2.30-3.90$ \\
\hline $\mathbf{1 0}$ & $\mathrm{Tv}_{10}$ & Thandarampatti & $\begin{array}{c}\text { Moderate white mycelium later } \\
\text { become deep green sporulation }\end{array}$ & $2.30-2.85$ & $1.90-3.75$ \\
\hline
\end{tabular}

Table.2 In vitro efficiency of Trichoderma viride against Sclerotium rolfsii $\left(\mathrm{SR}_{1}\right)$ by dual culture method

\begin{tabular}{|c|c|c|c|}
\hline $\begin{array}{c}\text { Isolates } \\
\text { number }\end{array}$ & $\begin{array}{c}\text { Mycelial growth } \\
(\mathbf{m m})\end{array}$ & $\begin{array}{c}\text { Inhibition zone } \\
(\mathbf{m m})\end{array}$ & $\begin{array}{c}\text { Per cent inhibition } \\
\text { over control }\end{array}$ \\
\hline $\mathbf{T v}_{\mathbf{1}}$ & 24.33 & 10.38 & 72.96 \\
\hline $\mathbf{T v}_{\mathbf{2}}$ & 29.84 & 9.31 & 66.84 \\
\hline $\mathbf{T v}_{\mathbf{3}}$ & 26.62 & 9.65 & 70.42 \\
\hline $\mathbf{T v}_{\mathbf{4}}$ & 21.65 & 11.30 & 75.94 \\
\hline $\mathbf{T}_{\mathbf{5}}$ & 20.56 & 12.58 & 77.15 \\
\hline $\mathbf{T v}_{\mathbf{6}}$ & 27.74 & 9.46 & 69.17 \\
\hline $\mathbf{T}_{\mathbf{7}}$ & 32.43 & 8.81 & 63.96 \\
\hline $\mathbf{T v}_{\mathbf{8}}$ & 37.33 & 7.05 & 58.52 \\
\hline $\mathbf{T} \mathbf{v}_{\mathbf{9}}$ & 34.15 & 7.71 & 62.05 \\
\hline $\mathbf{T} \mathbf{v}_{\mathbf{1 0}}$ & 39.85 & 6.80 & 55.72 \\
\hline $\mathbf{C o n t r o l}$ & $\mathbf{9 0 . 0 0}$ & $\mathbf{0 . 0}$ & $\mathbf{1 0 0}$ \\
\hline & S.Ed & 0.01 & \\
\hline
\end{tabular}

Data in parantheses indicate angular transformed values 
Table.3 Effect of culture filtrate of Trichoderma viride on the mycelia growth of Sclerotium rolfsii $\left(\mathrm{SR}_{1}\right)$ by Poison food technique

\begin{tabular}{|c|c|c|c|c|c|}
\hline T.no & $\begin{array}{c}\text { Concentration of } \\
\text { cultural filtrate }\end{array}$ & \multicolumn{2}{|c|}{ Solid medium } & \multicolumn{2}{|c|}{ Liquid medium } \\
\cline { 3 - 6 } & $(\boldsymbol{\%})$ & $\begin{array}{c}\text { Mycelial } \\
\text { growth } \\
\text { (mm) }\end{array}$ & $\begin{array}{c}\text { Per cent } \\
\text { inhibition over } \\
\text { control }(\boldsymbol{\%})\end{array}$ & $\begin{array}{c}\text { Mycelial } \\
\text { dry weight } \\
\text { (mg) }\end{array}$ & $\begin{array}{c}\text { Per cent } \\
\text { inhibition over } \\
\text { control (\%) }\end{array}$ \\
\hline $\mathbf{T}_{\mathbf{1}}$ & 10 & 38.65 & 57.05 & 320.83 & 28.84 \\
\hline $\mathbf{T}_{\mathbf{2}}$ & 20 & 26.11 & 70.98 & 112.45 & 75.02 \\
\hline $\mathbf{T}_{\mathbf{3}}$ & 30 & 10.38 & 88.46 & 69.72 & 84.51 \\
\hline $\mathbf{T}_{\mathbf{4}}$ & 40 & 0.00 & 100 & 4.21 & 99.06 \\
\hline $\mathbf{T}_{\mathbf{5}}$ & $\begin{array}{c}\text { Carbendazim } \\
(0.1 \%)\end{array}$ & 0.13 & 99.85 & 2.87 & 99.36 \\
\hline $\mathbf{T}_{\mathbf{6}}$ & Control & 90 & - & 450.25 & \\
\hline & S.Ed & 0.07 & & 1.21 & \\
\hline & CD (0.05) & 0.15 & & 2.58 & \\
\hline
\end{tabular}

Data in parantheses indicate angular transformed values

Plate.1 In vitro efficiency of Trichoderma viride against $S$. rolfsii (dual culture method)

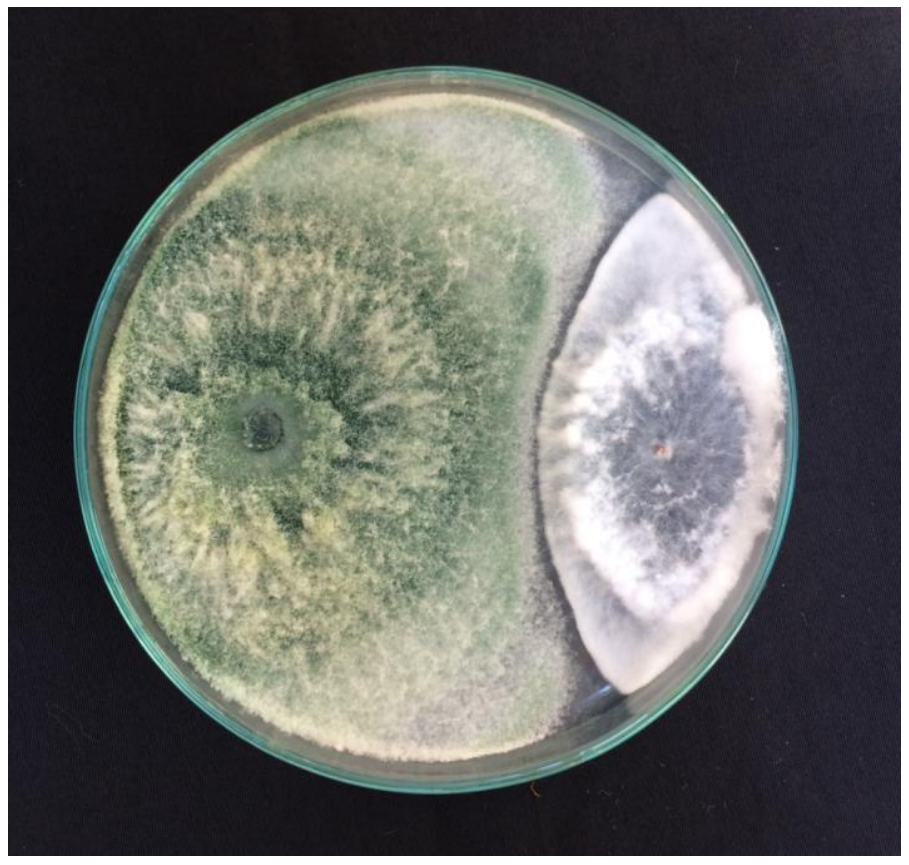


Plate.2 Evaluation of Trichoderma viride against S. rolfsii (Poison food technique)

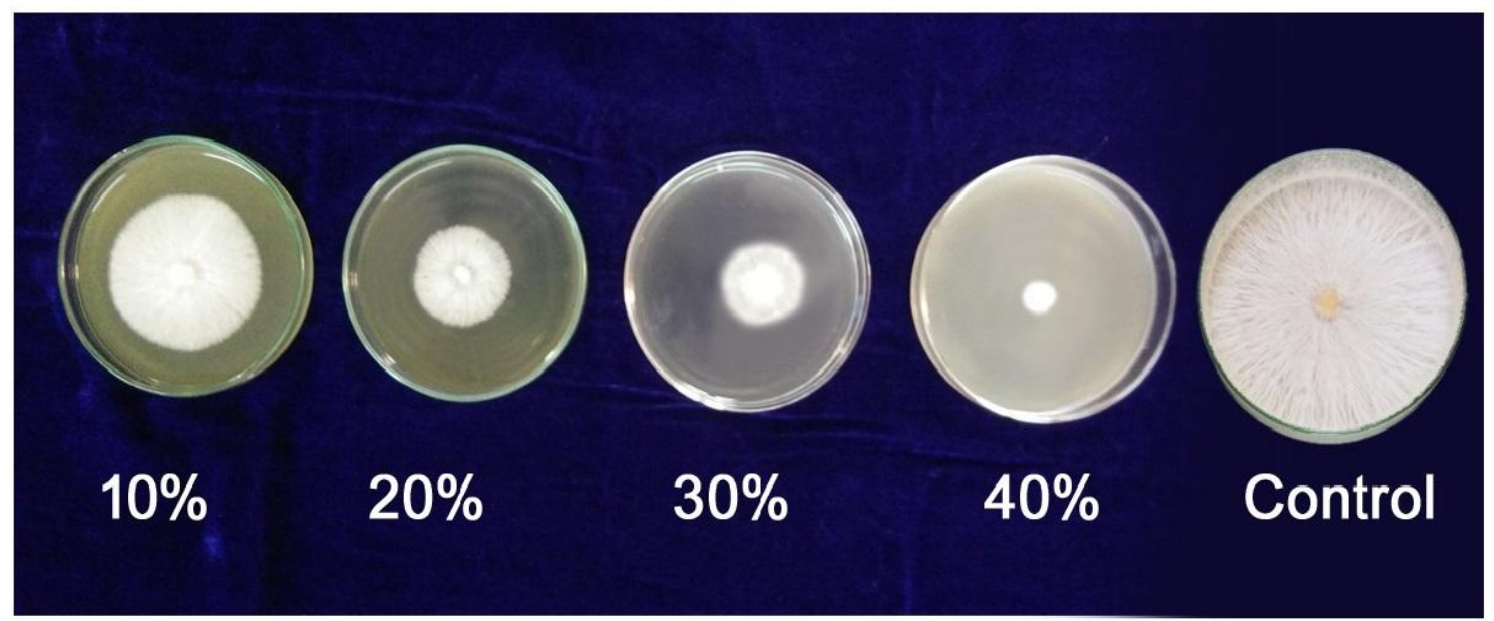

T. viride was found to inhibit in vitro growth $S$. rolfsii by coiling around mycelium of $S$. rolfsii resulting in lysis of hyphae (Fouzia and Seleem, 2005). Babu and Kumar (2008) also reported that $T$. harzianum-3 (Th-3) inhibited mycelial growth of $S$. rolfsii by 83 per cent in dual culture; the sclerotial population was also reduced by coiling around the aerial hyphae of $S$. rolfsii and produced haustoria like structure and penetrated the hyphae $S$. rolfsii and disorganized the protoplasm and controlled $S$. rolfsii. $T$. viride may also affect the growth of pathogen either through antibiosis (or) mycoparasitism. Besides they may also produce antifungal phenolic compounds (viridian, gliotoxin and Trichodermins) (Sababanday et al., 2008; Rahel Ratnakumari et al., 2011) which might be responsible for the inhibition of pathogen.

Effect of culture filtrate of $T$. viride on the mycelial growth and mycelial dry weight of $S$. rolfsii $\left(\mathrm{Sr}_{1}\right)$ by Poison food technique

The mycelial growth of $S$. rolfsii was found to be reduced with an increase in the conc. of culture filtrates of $T$. viride and the reduction was significantly the maximum in the case of T. viride with $38.65,26.11,10.38$ and 0.00 $\mathrm{mm}$ at 10, 20, 30 and 40 per cent conc. of the culture filtrate respectively against the maximum growth of $90 \mathrm{~mm}$ in the control. The same trend was maintained in the case of liquid medium assay. The flasks inoculated with pathogen and amended with culture filtrate of $T$. viride recorded significant reduction in the mycelial dry weight whereas, the flasks inoculated with $S$. rolfsii alone (control) recorded the maximum. The culture filtrate of all the $T$. viride isolates significantly inhibited the growth of $S$. rolfsii. Generally, an increase in the concentration of the culture filtrate reduced the growth of the pathogen. (Table 3) (Plate 2).

Siddanagour (2005) reported reduction in mycelial growth of $S$. rolfsii when PDA amended with culture filtrates Trichoderma spp. culture filtrates of Trichoderma spp inhibited the mycelial growth and sclerotial germination of $S$. sclerotiorum (Kapil and Kapoor 2005). Vengatesh (2013) reported that culture filtrate of isolates $-\mathrm{I}_{2}$ (THA) recorded complete inhibition of $S$. rolfsii at $15 \%$ concentration. The cell free culture filtrate of $T$. viride and T. harzianum showed 100 per cent mycelial growth inhibition at 60 and 80 per cent conc. against $S$. rolfsii (Swathi et al., 2015). These earlier reports are in line with the present findings. It was clearly stated that 
T. viride isolated from rhizosphere soil of tuberose have strong and virulent antagonist against stem rot of tuberose caused by $S$. rolfsii. The combination of bulb treatment and soil application is found to be very effective.

\section{References}

Babu K V, Kumar M R (2008) Mycoparasitic activity of Trichoderma harzianum against stem rot pathogen (Sclerotium rolfsii) of groundnut. Journal of Mycology and Plant Pathology 38(3): 593-595

Chet I (1987). Trichoderma - Application, mode of action and potential as a biocontrol agent of soilborn plant pathogenic fungi, 137-160 p. In: Villey $\mathbf{J}$ and Sons (Eds.). Innovative approaches to Plant Disease Control, N.Y., Toronto, Singapour.

Darvin G, Venkatesh I, Reddy GN (2013) Evaluation of Trichoderma spp. against Sclerotium rolfsii in vitro. International journal of applied biology and pharmaceutical technology 4(4): 268-27

Dennis L, Webstar J (1971) Antagonistic properties of species-groups of Trichoderma. The production of nonvolatile antibiotics. Trans Bri Mycol Soc 57: 25-39

Domsch K H, Gans W, Anderon T H (1980) Compendium of soil fungi. Academic Press Ltd., London 859

Dwivedi S K, Ganesh Prasad (2016) Integrated Management of Sclerotium rolfsii: An Overview. European Journal of Biomedical and Pharmaceutical sciences 3(11): 137146

Elad Y, Chet I (1983) Improved selective media for isolation of Trichoderma or Fusarium spp. Phytoparasitca 11: 5558

Elad Y, Chet I, Henis Y (1983). Parasitism of
Trichoderma spp. on Rhizoctonia solani and Sclerotium rolfsii - scanning electron microscopy and fluorescence microscopy. Phytopathology 73:85-88.

Fouzia Y, Qub, Seleem S (2005) Pathogenecity of Sclerotium rolfsii on different crops and effects of inoculum density on colonization of mungbean and sunflower roots. Pakistan Journal of Botany 37:175-780

Gowdranagamma, Nagaraja A, Somashekharkonda (2015) In vitro Bio-Efficacy of Bio-agents against Sclerotium rolfsii Sacc. causing stem rot disease in Groundnut. Trends in Biosciences 8(10): 2504-2508

Harman GE, Chet I, Baker R (1980). Trichoderma hamatum effects on seed and seedlings disease induced in radish and pea by Pythium spp. or Rhizoctonia solani. Phytopathology 70:1167-1172.

Hirpara D G, Gajera H P, Hirpara H Z and Golakiya B A (2017) Antipathy of Trichoderma against Sclerotium rolfsii Sacc. Evaluation of cell wallDegrading Enzymatic Activities and molecular Diversity Analysis of Antagonists. J Mol Microbiol Biotechnol 27: 22-28

Kakade D S (2007) Studies on stem rot of tuberose (Polianthes tuberosa L.) caused by Sclerotium rolfsii. Ph.D thesis, MPKV, Rahuri. Pp 97-98

Kapil, Kapoor A S (2005) Management of white rot of pea incited by (Sclerotinia sclerotiorum) using Trichoderma spp and biopesticides. Indian Phytopathology 58:10-17

Karthikeyan V, Sankaralingam A, Nakkeeran $S$ (2006) Biological control of groundnut stem rot caused by Sclerotium rolfsii (Sacc.). Archives of Phytopathology and Plant Protection 39(3): 239-246

Padmaja M, Narendra K, Swathi J, Sowjanya 
K M, Jawahar Babu P, Satya A K (2013) In vitro antagonism of native isolates of Tricoderma spp against Sclerotium rolfsii. International Journal of Research in Pharmaceutical and Biomedical Sciences 4 (3): 886-891

Pan P, Mukherji R, Bhagat S (2013) Evaluation of Trichoderma spp. against soil borne plant pathogens. Anuals of Plant Protection Science 21(1): 176-223

Papavizas G C (1985). Trichoderma and Gliocladium: Biology, ecology and potential for biocontrol. Ann Rev Phytopath 23:13-54.

Parmar H J, Mohamed M H, Bodar N P, Umrania V V, Patel S V, Lakhani H N (2015) In vitro antagonism between phytopathogenic fungi Sclerotium rolfsii and Trichoderma Strains. International Journal Applied Sciences Biotechnology 3(1): 16-19

Prasun K, Kanthadai R (1997). Effect of temperature on antagonistic and biocontrol potential of Trichoderma sp. on Sclerrotium rolfsii. Mycopathologia 139:151-155.

Rahel Ratnakumari Y, Nagamani A, Bhramaramba S (2011) Mycofungicide to control the callor-rot pathogen of Mentha arvensis L. Pharmacology online 1:77-83

Ramzan N, Noreen N, Perveen Z, Shahzad S (2016) Effect of seed pelleting with bio-control agents on growth and colonization of roots of mungbean by root-infecting fungi. J Sci Food Agric 7553

Sababandy, Faheem amin, Razolan V K, Mohiddin, F A, Bhat K A (2008) Potential of Trichoderma Species as Biocontrol agents of Soil borne fungal Propagles. Journal of Phytology 2: 3841

Sala E, Burzi P L, Galletti S M, Cerato C
(2007) Multiple effects of Trichoderma spp. applied to sugar beet towards soil-borne pathogens. Bulletin-OILB/SROP 6(1): 199-202

Savitha M J, Subbaraman Sriram (2015) Morphological and molecular identification of Trichoderma isolates with biocontrol potential against Phytophthora blight in red pepper. Pest management in horiticuture ecosystem 21(2): 194- 202

Sharon E, Bar-Eyal M, Chet I, Herra-Estrella A, Kleified O, Spigel Y (2001). Biological control of the root-knot nematode Meloidogyne javanica by Trichoderma harzianum. Phytopathology. 91: 687-693.

Siddanagoudar R A (2005) Effect of bioagents and their metabolites on Sclerotium rolsfii Sacc. of groundnut. M.Sc. (Ag), Thesis, University of Agricultural Sciences, Dharwad PP 110

Singh S P, Singh H B, Singh D K (2014) Biocontrol potential of mixture of Trichoderma isolates on damping-off and collar rot of tomato. The Bioscan and international Quality Journal of Life Science 9(3):1301-1304

Sivasakthi S, Usharani G, Saranraj P (2014) Biocontrol potentiality of plant growth promoting bacteria (PGPR)Pseudomonas fluorescens and Bacillus subtilis; a review. Afr J Agricultural Research 9: 1265-1277

Srivastava R, Khalid A, Singh U S, Sharma A K (2010) Evaluation of arbuscular mycorrhizal fungus, fluorescent Pseudomonas and Trichoderma harzianum formulation against Fusarium oxysporum f. sp. lycopersici for the management of tomato wilt. Biological Control 53: 24-31

Swathi B, Patibanda A K, Prasuna R P (2015) Antagonistic efficacy of Trichoderma species on Sclerotium rolfsii in vitro. IOSR Journal of Agriculture and 
Veterinary Science 8 (7): 19 - 22

Thahir Basha S, Radhaiah A, Nagalakshmi D M, Eswara Reddy N P (2012) Biocontrol potential of indigenous Pseudomonas spp. against Sclerotium rolfsii causing stem rot of groundnut. International Journal of food, Agriculture and Veterinary Sciences 2: $134-141$

Theradimani M, Thangaselvabai $\mathrm{T}$, Swaminathan V (2018) Management of Tuberose Root Rot Caused by Sclerotium rolfsii by Biocontrol Agents and Fungicides. Advances in Floriculture and Urban Horticulture, ICAR, New Delhi 308-311
Venkatesh A (2013) Studies on Biological Management of Collar rot of Pepper mint Caused by Sclerotium rolfsii Sacc. M.sc.Thesis, Annamalai University, Tamil Nadu, India

Wells H D, Bell D K, Jaworski C A (1972). Efficacy of Trichoderma harzianum as a biocontrol for Sclerotium rolfsii. Phytopathology. 62: 442-447.

Zape A S, Gade R M, Singh R, Deshmukh V A (2014) Efficacy of different antagonist against the Sclerotium rolfsii, Rhizoctonia solani, and Fusarium solani. The Bioscan, 9(4): 1431-1434.

\section{How to cite this article:}

Sankara Reddy, N. H., T. Sivakumar and Balabaskar, P. 2021. Bio-Control Efficiency of Trichoderma viride against Stem Rot of Tuberose Caused by Sclerotium rolfsii. Int.J.Curr.Microbiol.App.Sci. 10(11): 407-415. doi: https://doi.org/10.20546/ijcmas.2021.1011.046 